UDC 633.15:577.34:58.087

\title{
THE STUDY BY THE METHODS OF INFRARED SPECTROSCOPY OF THE STRETCHING AND TWISTING VIBRATIONS OF CHEMICAL BONDS IN FUNCTIONAL GROUPS OF ORGANIC COMPOUNDS CONTAINED IN GRAINS OF MAIZE INBRED LINES
}

\author{
Č.N. RADENOVIĆ1,2*, G.V. MAKSIMOV ${ }^{3}$, V.V. SHUTOVA ${ }^{4}$, N.S. DELIĆ ${ }^{1}$, \\ M.V. MILENKOVIĆ ${ }^{1}$, M.D. PAVLOVIĆ ${ }^{5}$, M.V. BELJANSKI ${ }^{5}$ \\ ${ }^{1}$ Maize Research Institute, Zemun Polje, Belgrade, Serbia \\ ${ }^{2}$ University of Belgrade, Faculty of Physical Chemistry, Belgrade, Serbia \\ ${ }^{3}$ M.V. Lomonosov Moscow State University, Faculty of Biology, Moscow, Russia \\ ${ }^{4}$ N.P. Ogarev Mordovia State University, Faculty of Biology, Saransk, Russia \\ 5 Institute of General and Physical Chemistry, BioLab, Belgrade, Serbia \\ *Corresponding author's e-mail: radenovic@sbb.rs
}

The infrared spectroscopy was applied on kernels of the following maize inbred lines with significant traits: ZPPL 186, ZPPL 225 and M1-3-3 Sdms, with the aim to determine structural properties of organic compounds and their unstable state. The set hypothesis was that it was necessary to observe the existence of numerous and different spectral bands, not studied so far, occurring in various patterns (bands of low intensity, single or grouped) and to explain the nature and the dynamics of their formation. Such spectral bands were observed in the wave number range of $400-2925 \mathrm{~cm}^{-1}$ and are caused by the different types of vibration movements (valence and deformation vibrations) of organic compounds: alkenes, aromatic compounds, alcohols, ethers, carboxylic acids, esters, amines, amides, alkanes, nitro compounds, ketones, aldehydes, alkynes, nitriles and phenols. In this way, it is possible to establish not only the structure of organic compounds of kernels of observed maize inbred lines, but also it is possible to point out to their unstable, conformational and functional properties. The importance of intensity, shape and kinetics of spectral bands, expressing unstable processes in biological systems and bioactive organic molecules, has been studied and emphasised for the first time.

Key words: Zea mays L., maize inbred lines, grain, infrared spectra, spectral bands.

Nowadays, the fundamental improvement in the diagnosis of the state of organs and vital functions of the whole plant at the molecular level is achieved with modern methods of spectroscopy. The vibrational spectroscopy (infrared and Raman) is an unavoidable method in the analysis of infrared spectra of organic molecules resulting from molecular vibrations, thus it is possible to obtain many other results about the structure of the studied systems [1-5].

Our previous manuscripts [6-9] present studies on the structural changes of carotenoids in kernels of various maize inbred lines and hybrids.

(C) Č.N. RADENOVIĆ, G.V. MAKSIMOV, V.V. SHUTOVA, N.S. DELIĆ, M.V. MILENKOVIĆ, M.D. PAVLOVIĆ, M.V. BELJANSKI, 2018 
It was also shown that the structure of these molecules may be used as molecular markers in the evaluation of agronomic values of the maize inbred lines and hybrids. Our more recent papers [10-12] discuss studies on the formation of infrared spectra, and in particular of 5-6 spectral bands that were most pronounced. No other, numerous and less developed spectral bands, were analysed in these studies.

The method of infrared spectroscopy was applied in this study with the aim to analyse weak and insufficiently differentiated spectral bands, and thus, to identify the unstable state of the system, and life functions of kernels of observed maize inbred lines. It was shown that the infrared spectroscopy can also, in addition to the other methods, determine the structure of organic compounds in kernels of studied maize inbred lines [13].

The objective of this study was to develop the methodology for analyses of numerous spectral bands of low intensity, different shapes and kinetics, in order to identify functional groups and to determine the structure and stability of organic compounds in kernels of analysed maize inbred lines.

\section{Material and Methods}

Plant material. The three elite maize inbred lines, ZPPL 186, ZPPL 225 and M1-3-3 Sdms, derived at the Maize Research Institute, Zemun Polje, Belgrade, Serbia were used as a material in this study. Morphological and agronomic traits of observed maize inbred lines, including those relevant to breeding and seed production, are thoroughly described in our previously published manuscript [10].

Methods. The method of infrared spectroscopy applied to the grain of maize inbred lines includes spectrophotometers that use the infrared spectrum region. In principle, they do not significantly differ from spectrophotometers in the ultraviolet-visible spectrum. They do not differ much in the sequence of components. Specificities, however, occur in the very principle of the work of the spectrophotometer. The fundamental differences relate to the source of radiation, nature of samples, the principle of absorption of radiation as well as the use of various detectors (thermal and photodetectors) $[1,5]$.

Today, a special type of spectrophotometers, based on the principles of interferometry is used. Interferometers do not produce the spectrum itself, but an interferogram, which is then processed by a computer into a common spectrum. This is co-called Fourier transformation, and hence the name Fourier Transform Spectroscopy (FTS). These devices are especially suitable for use in the far-infrared region and are characterised by good resolution $[11,12]$.

In order to register the infrared spectrum of the observed maize inbred lines, kernels were homogenised and pressed into the tablet form with the addition of potassium bromide $(\mathrm{KBr})$. The spectrum was recorded with the Furier Transform Infrared Spectrometer, Shimadzu IR-Prestige 21, within the spectral range of $400-4000 \mathrm{~cm}^{-1}$.

This method has been described in details in our previous manuscripts $[11,12]$, including the modus operandi and the optical scheme of the device for registering infrared spectra. 


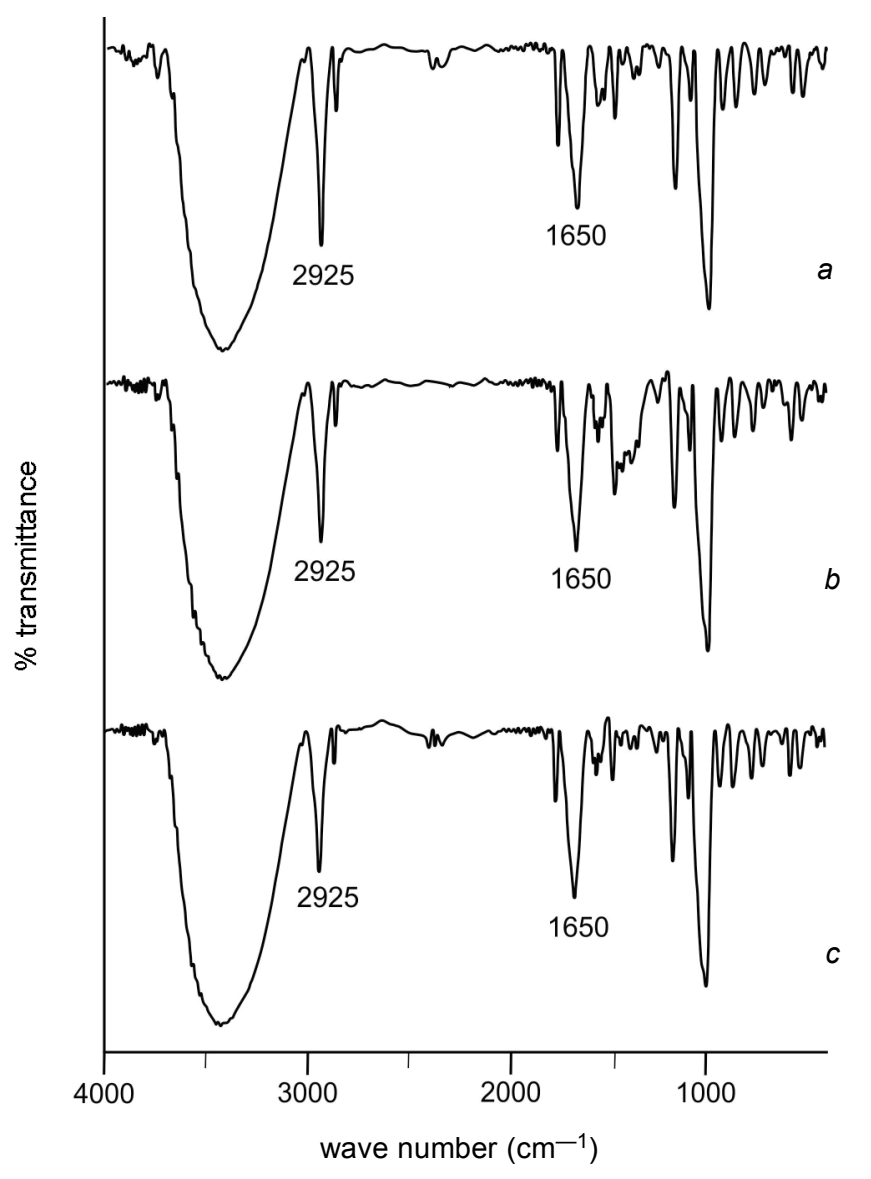

FT-MIR spectra of the grain of three maize inbred lines:

$a-$ ZPPL 186; $b-$ ZPPL 225; $c-$ M1-3-3 Sdms.

Selected vibrational bands, assigned to $\mathrm{CH}_{2}$ asymmetric stretching at $2925 \mathrm{~cm}^{-1}$ (mainly in lipids) and amide $\mathrm{I}$ at $1650 \mathrm{~cm}^{-1}(\mathrm{C}-\mathrm{N}$ and $\mathrm{C}=\mathrm{O}$ stretching $)$ in proteins

\section{Results and discussion}

Kernels of observed maize inbred lines with significant traits (ZPPL 186, ZPPL 225 and M1-3-3 Sdms) was homogenised and formatted into the tablet and thus prepared for registering the complete infrared spectrum (Fig.). Generally, analysed infrared spectra for three maize inbred lines were characterised by numerous spectral bands. The number of bands was up to 40 within the range of the wave number from 400 to $4000 \mathrm{~cm}^{-1}$. The registered spectral bands were of the unequal intensity, different shapes and kinetics. Distinctively pronounced spectral bands (4-6) were analysed and presented in our recently published paper [10]. However, in addition to these bands in the infrared spectrum of kernels of maize inbred lines, a series of very different spectral bands appeared - high or low intensity bands, clearly separated or grouped and spectral bands of a complex structure. Such spectral bands could not be found in the literature and had not been analysed yet. Our study was actually focused on stated bands of low intensities and with specific kinetic parameters. A careful consideration and analysis of grain spectra of observed maize inbred lines (Fig.) shows a great 
Major absorption bands in FT-MIR spectra in grain of maize inbred lines: ZPPL 186, ZPPL 225 and M1-3-3 Sdms

\begin{tabular}{|c|c|c|c|c|}
\hline \multicolumn{3}{|c|}{ Maize inbred lines } & \multirow{2}{*}{$\begin{array}{c}\text { Assignment of the major } \\
\text { IR absorption bands of } \\
\text { biological macromolecules } \\
\text { in functional groups }\end{array}$} & \multirow{2}{*}{$\begin{array}{l}\text { Assignment of the IR } \\
\text { absorption bands of } \\
\text { organic molecules in } \\
\text { functional groups }\end{array}$} \\
\hline ZPPL 186 & ZPPL 225 & M1-3-3 Sdms & & \\
\hline $\begin{array}{l}\text { Wave number } \\
\text { of spectral } \\
\text { band, } \mathrm{cm}^{-1}\end{array}$ & $\begin{array}{l}\text { Wave number } \\
\text { of spectral } \\
\text { band, } \mathrm{cm}^{-1}\end{array}$ & $\begin{array}{l}\text { Wave number } \\
\text { of spectral } \\
\text { band, } \mathrm{cm}^{-1}\end{array}$ & $\begin{array}{l}\text { Wave number of spectral } \\
\text { bands, } \mathrm{cm}^{-1}\end{array}$ & $\begin{array}{l}\text { Wave number of spectral } \\
\text { bands, } \mathrm{cm}^{-1}\end{array}$ \\
\hline $3750 \mathrm{~m}$ & $3750 \mathrm{w}$ & $3750 \mathrm{w}$ & & $\begin{array}{l}3590-3650 \mathrm{v}, \mathrm{O}-\mathrm{H}, \\
\text { monomeric alcohols, } \\
\text { phenols } \\
3500-3650 \mathrm{~m}, \mathrm{O}-\mathrm{H}, \\
\text { monomeric carboxylic } \\
\quad \text { acid }\end{array}$ \\
\hline $\begin{array}{c}\mathbf{3 4 2 0} \mathbf{s} \\
(3000-3600) \\
\text { Fig. }(b)\end{array}$ & $\begin{array}{c}3420 \text { s } \\
(3000-3600) \\
\text { Fig. }(b)\end{array}$ & $\begin{array}{l}\mathbf{3 4 2 0} \mathbf{s} \\
(3000-3600) \\
\text { Fig. }(b)\end{array}$ & $\begin{array}{l}\text { 3200-3500, OH stretch } \\
\text { 3290, Amide A } \\
(\mathrm{N}-\mathrm{H} \text { stretch); protein } \\
3050, \text { Amide B } \\
\mathrm{N}-\mathrm{H} \text { bending } 1^{\mathrm{st}} \\
\text { overtone; protein }^{\mathrm{b}}\end{array}$ & $\begin{array}{c}3200-3600 \mathrm{v}, \mathrm{O}-\mathrm{H}, \\
\text { water, hydrogen-bonded } \\
\text { alcohols, phenols } \\
3300-3500 \mathrm{~m}, \mathrm{~N}-\mathrm{H}, \\
\text { amines, amides } \\
3300 \mathrm{~s}, \mathrm{C}-\mathrm{H} \text {, alkynes }\end{array}$ \\
\hline \multirow[t]{2}{*}{$3010 \mathrm{w}$} & \multirow[t]{2}{*}{$3010 \mathrm{w}$} & \multirow[t]{2}{*}{$3010 \mathrm{w}$} & 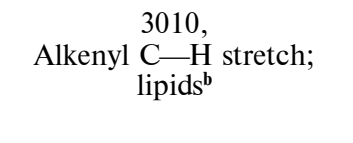 & \multirow[t]{2}{*}{$\begin{array}{l}3010-3100 \mathrm{~m}, \mathrm{C}-\mathrm{H} \\
\text { aromatic rings } \\
3010-3095 \mathrm{~m}, \mathrm{C}-\mathrm{H} \\
\text { alkenes }\end{array}$} \\
\hline & & & $\begin{array}{l}\text { 2956, } \mathrm{CH}_{3} \text { asymmetric } \\
\text { stretch; lipids, proteins }\end{array}$ & \\
\hline \multirow[t]{2}{*}{$2925 \mathrm{~s}$} & \multirow[t]{2}{*}{$2925 \mathrm{~s}$} & \multirow[t]{2}{*}{$2925 \mathrm{~s}$} & $\begin{array}{l}\text { 2925, } \mathrm{CH}_{2} \text { asymmetric } \\
\text { stretch; lipids, proteins }\end{array}$ & \\
\hline & & & $\begin{array}{c}2873 \mathrm{~cm}^{-1}, \mathrm{CH}_{3} \\
\text { symmetric stretch; lipids, } \\
\text { proteins }\end{array}$ & $\begin{array}{c}2850-2970 \mathrm{~s}, \mathrm{C}-\mathrm{H}, \\
\text { alkanes }\end{array}$ \\
\hline $2850 \mathrm{~m}$ & \multirow[t]{2}{*}{$2850 \mathrm{~m}$} & $2850 \mathrm{~m}$ & $\begin{array}{l}\text { 2854, } \mathrm{CH}_{2} \text { symmetric } \\
\text { stretch; lipids, proteins }\end{array}$ & $\begin{array}{l}2500-2700 \mathrm{~b}, \mathrm{O}-\mathrm{H}, \\
\text { hydrogen-bonded } \\
\text { carboxylic acids }\end{array}$ \\
\hline $2375 / 2340 \mathrm{w}$ & & $\begin{array}{c}2375 / \\
2340 / 2300 \mathrm{w}\end{array}$ & $\begin{array}{l}2370,2340 \mathrm{~cm}^{-1} \\
\mathrm{CO}_{2} \text { bend }^{\mathrm{c}}\end{array}$ & \multirow[t]{2}{*}{$\begin{array}{c}2210-2280 \mathrm{~s}, \mathrm{C} \equiv \mathrm{N}, \\
\text { nitriles } \\
2100-2260 \mathrm{v}, \mathrm{C} \equiv \mathrm{C}, \\
\text { alkynes }\end{array}$} \\
\hline $1740 \mathrm{~m}$ & $1740 \mathrm{~m}$ & $1740 \mathrm{~m}$ & $\begin{array}{l}\text { 1735, Ester } \mathrm{C}=\mathrm{O} \text { stretch; } \\
\text { lipids }^{\mathrm{b}}\end{array}$ & \\
\hline $1650 \mathrm{~s}$ & $1650 \mathrm{~s}$ & $1650 \mathrm{~s}$ & $\begin{array}{l}\text { 1655, Amide I (protein } \\
\mathrm{C}=\mathrm{O} \text { stretch), } \alpha \text {-helices } \\
1636, \text { Amide I (protein } \\
\mathrm{C}=\mathrm{O} \text { stretch), } \beta \text {-sheet }\end{array}$ & $\begin{array}{c}1690-1760, \mathrm{C}=\mathrm{O}, \\
\text { aldehydes, ketones, } \\
\text { karboxylic acids, esters } \\
1650, \mathrm{H}-\mathrm{OH} \text { streching, } \\
\text { water } \\
1610-1680 \mathrm{v}, \mathrm{C}=\mathrm{C}, \\
\text { alkenes }\end{array}$ \\
\hline $1550 \mathrm{~m}$ & $1550 \mathrm{~m}$ & $1550 \mathrm{~m}$ & $\begin{array}{l}1545, \text { Amide II } \\
\text { (protein } \mathrm{N}-\mathrm{H} \text { bending } \\
\text { and } \mathrm{C}-\mathrm{N} \text { stretching) }\end{array}$ & $\begin{array}{l}1500-1600 \mathrm{v}, \\
\mathrm{C}=\mathrm{C}, \text { aromatic rings } \\
1500-1570 \mathrm{~s}, \mathrm{NO}_{2},\end{array}$ \\
\hline \multirow[t]{2}{*}{$1515 \mathrm{~m}$} & \multirow[t]{2}{*}{$1515 \mathrm{~m}$} & \multirow[t]{2}{*}{$1515 \mathrm{~m}$} & $\begin{array}{l}1590-1595,1510, C=C \\
\text { in plane aromatic } \\
\text { vibrations, lignin }^{\mathrm{d}}\end{array}$ & \\
\hline & & & $\begin{array}{l}1515, \text { Tyrosine ring } \\
\text { breathing vibration } \\
(\mathrm{C}-\mathrm{C} / \mathrm{C}=\mathrm{C} \text { stretching })^{\mathrm{b}}\end{array}$ & \\
\hline
\end{tabular}

ISSN 2308-7099. Физиология растений и генетика. 2018. Т. 50. № 4 
Č.N. RADENOVIĆ, G.V. MAKSIMOV, V.V. SHUTOVA et al.

\begin{tabular}{|c|c|c|c|c|}
\hline \multicolumn{5}{|l|}{ Continuation } \\
\hline \multicolumn{3}{|c|}{ Maize inbred lines } & \multirow{2}{*}{$\begin{array}{c}\text { Assignment of the major } \\
\text { IR absorption bands of } \\
\text { biological macromolecules } \\
\text { in functional groups }\end{array}$} & \multirow{2}{*}{$\begin{array}{l}\text { Assignment of the IR } \\
\text { absorption bands of } \\
\text { organic molecules in } \\
\text { functional groups }\end{array}$} \\
\hline ZPPL 186 & ZPPL 225 & M1-3-3 Sdms & & \\
\hline $\begin{array}{l}\text { Wave number } \\
\text { of spectral } \\
\text { band, } \mathrm{cm}^{-1}\end{array}$ & $\begin{array}{l}\text { Wave number } \\
\text { of spectral } \\
\text { band, } \mathrm{cm}^{-1}\end{array}$ & $\begin{array}{l}\text { Wave number } \\
\text { of spectral } \\
\text { band, } \mathrm{cm}^{-1}\end{array}$ & $\begin{array}{l}\text { Wave number of spectral } \\
\text { bands, } \mathrm{cm}^{-1}\end{array}$ & $\begin{array}{l}\text { Wave number of spectral } \\
\text { bands, } \mathrm{cm}^{-1}\end{array}$ \\
\hline $1465 \mathrm{~m}$ & $1465 \mathrm{~m}$ & $1465 \mathrm{~m}$ & $\begin{array}{l}\text { 1467, } \mathrm{CH}_{2} \text { bending; } \\
\text { lipids, protein }\end{array}$ & $\begin{array}{l}1340-1470 \mathrm{~s} \\
\mathrm{C}-\mathrm{H}, \text { alkanes }\end{array}$ \\
\hline \multirow[t]{2}{*}{$1425 \mathrm{w}$} & $\begin{array}{c}1420 \\
(1300-1500) \\
\text { Fig. }(b)\end{array}$ & $1425 \mathrm{w}$ & 1420, glucan $^{\mathrm{d}}$ & \multirow[t]{2}{*}{$\begin{array}{l}1300-1370 \mathrm{~s}, \mathrm{NO}_{2}, \\
\text { nitro compounds }\end{array}$} \\
\hline & $\begin{array}{c}1400 \\
(1300-1500) \\
\text { Fig. }(b)\end{array}$ & & $\begin{array}{c}\text { 1400, COO symmetric } \\
\text { stretching; proteins, fatty } \\
\text { acids }^{\mathrm{b}}\end{array}$ & \\
\hline $1380 / 1340 \mathrm{w}$ & $\begin{array}{c}\mathbf{1 3 8 0} / \mathbf{1 3 5 0} \mathbf{w} \\
(1300-1500) \\
\text { Fig. }(b)\end{array}$ & $1380 / 1350 \mathrm{w}$ & $\begin{array}{l}\text { 1380, } \mathrm{CH}_{3} \text { bending; } \\
\text { lipids, proteins }{ }^{\mathrm{b}}\end{array}$ & \multirow{5}{*}{$\begin{array}{l}1180-1360 \mathrm{~s}, \mathrm{C}-\mathrm{N} \text {, } \\
\text { amines, amides } \\
1050-1300 \mathrm{~s}, \mathrm{C}-\mathrm{O} \\
\text { alcohols, ethers, } \\
\text { carboxylic acids, esters }\end{array}$} \\
\hline \multirow{4}{*}{$1246 / 1225 \mathrm{w}$} & & & $\begin{array}{l}\text { 1280, Amide III of } \\
\text { collagen }^{\mathrm{b}}\end{array}$ & \\
\hline & $1246 \mathrm{w}$ & $1246 \mathrm{w}$ & 1246 , cellulose ${ }^{\mathrm{d}}$ & \\
\hline & & $1225 \mathrm{w}$ & $\begin{array}{c}1220-1240, \mathrm{PO}_{2} \\
\text { asymmetric stretch; } \\
\text { nucleic acids, lipids } \\
\text { Amide III of collagen }\end{array}$ & \\
\hline & & & $\begin{array}{l}1204 \text { Amide III of } \\
\text { collagen }\end{array}$ & \\
\hline $\begin{array}{l}1160 \mathrm{~s} \\
1080 \mathrm{~m} \\
\mathbf{1 0 0 0 \mathrm { s }}\end{array}$ & $\begin{array}{l}1160 \mathrm{~s} \\
1080 \mathrm{~m} \\
1000 \mathrm{~s}\end{array}$ & $\begin{array}{l}1160 \mathrm{~s} \\
1080 \mathrm{~m} \\
1000 \mathrm{~s}\end{array}$ & $\begin{array}{c}1000-1200, \mathrm{C}=\mathrm{O} \\
\text { stretching; carbohydrates }\end{array}$ & \multirow[b]{2}{*}{$\begin{array}{l}675-995 \mathrm{~s}, \mathrm{C}-\mathrm{H}, \\
\text { alkenes } \\
670-990 \mathrm{~s}, \mathrm{C}-\mathrm{H}, \\
\text { aromatic rings }\end{array}$} \\
\hline $\begin{array}{l}930 \mathrm{~m} \\
850 \mathrm{~m} \\
780 \mathrm{~m} \\
720 \mathrm{~m} \\
580 \mathrm{~m} \\
520 \mathrm{~m}\end{array}$ & $\begin{array}{c}930 \mathrm{~m} \\
850 \mathrm{~m} \\
780 \mathrm{~m} \\
720 \mathrm{~m} \\
670 \mathrm{w} \\
615 / 580 \mathrm{~m} \\
520 \mathrm{~m}\end{array}$ & $\begin{array}{l}930 \mathrm{~m} \\
850 \mathrm{~m} \\
780 \mathrm{~m} \\
720 \mathrm{~m} \\
580 \mathrm{~m} \\
520 \mathrm{~m}\end{array}$ & $\begin{array}{c}1080, \mathrm{PO}_{2} \text { symmetric } \\
\text { stretch; nucleic acids, } \\
\text { lipids } \\
750-950 \text {, conformers a } \\
\text { and b of pyranoid and } \\
\text { furanoid ring vibrations of } \\
\text { mono- and } \\
\text { polysaccharides }\end{array}$ & \\
\hline
\end{tabular}

Abbreviations:

$\mathrm{s}-$ strong intensity, $\mathrm{m}-$ medium intensity, $\mathrm{w}-$ weak intensity, $\mathrm{v}-$ variable intensity of spectral bands. Sources: ${ }^{\mathrm{a}}[19],{ }^{\mathrm{b}}[20],{ }^{\mathrm{c}}[21],{ }^{\mathrm{d}}[22],{ }^{\mathrm{e}}[23]$.

number of spectral bands in the wave number range of $400-2040 \mathrm{~cm}^{-1}$ for all three maize inbred lines.

According to their kinetic parameters, they differed considerably from one another. There were at least three classes. Similar spectral bands were formed within the range of the wave number of 400-950 $\mathrm{cm}^{-1}$. Somewhat different spectral bands were formed within the range of the wave number of $1200-1600 \mathrm{~cm}^{-1}$. Finally, there were spectral bands that were formed within the ranges of the wave numbers of $1680-2400$ and $1680-2800 \mathrm{~cm}^{-1}$ (Fig.). According to our hypothesis, the low intensity spectral bands and with different kinetic parameters suggest an unstable (excited) state of the biological system [13-16]. Furthermore, the excited state is expressed in 
certain functional groups of organic compounds that are presented in Table. It should not be forgotten that the unstable states of the biological system (tissue, cells, membranes) are a consequence of the excited state of molecules, radicals, atoms and/or ions and that they are inevitably caused by the occurrence of different movement modes (oscillation, vibration, rotations, translations). The similar events happen in the process of the ion oscillatory transport through the excited membrane [15, 16]. Moreover, today, beyond any doubt, great attention is paid to the contemporary study of the biological systems, seeking for information on genomes and proteomes and primarily their metabolomes, i.e. the concentration of all metabolites and their interactions. This is enabled by the application of infrared spectroscopy in studying of the structure properties of organic compounds of kernels of maize inbred lines [11-13].

Based on everything stated above, at least two questions may be posed. First, how to obtain reliable information on the existence of different biogenic organic molecules (substances), whose specificities regarding vibrations cause the appearance of different spectral bands. Second, are there any essential differences in kernels of observed maize inbred lines (ZPPL 186, ZPPL 225 and M1-3-3 Sdms), in regard to infrared spectra. If such differences exist, then it can be concluded that there are various organic compounds with different structural properties in kernels of studied maize inbred lines.

The answer to the posed questions can be largely found out in our obtained results presented in Table and Fig. The careful analysis of literature data, i.e. of the intensity, shape, kinetic values, as well as the range of the wave number of spectral bands $[17,18]$ provides the identification of functional groups of organic compounds. When the same parameters presented in Table and Fig. are compared, it can be concluded that structural properties of organic compounds of inbreds ZPPL 186 and M1-3-3 Sdms were similar, while those of the inbred ZPPL 225 differed, to a lesser degree.

Finally, according to the gained results the following can be added: the importance of intensity, shape and kinetics of spectral bands expressing unstable processes in biological systems and bioactive organic molecules, has been studied and emphasised for the first time.

\section{REFERENCES}

1. Vasiliev, A.V., Grinenko, E.V., Shchukin, A.O. \& Fedulina, T.G. (2007). Infrared spectroscopy of organic and natural compounds. SPb: SPb. Gos. Lesotech. Acad. [in Russian].

2. Sverdlov, L.M., Kovner, M.A. \& Krainov, E.P. (1970). Vibrational spectra of polyatomic molecules. Moskva: Nauka [in Russian].

3. Tarasevich, B.N. (2012). IR spectra of the main classes of organic compounds. Moskva: Izd. MGU [in Russian].

4. Krimm, S. \& Bandekar, J. (1986). Vibrational spectroscopy and conformation of peptides, polipeptides and proteins. Advances in Protein Chemistry, 38, pp. 181-364.

5. Ribnikar, S. (1985). Infracrvena i ramanska spektroskopija. In: Fizickohemijske metode (pp. 251-266). Beograd: Rad.

6. Radenović, Č., Jeremić, M., Maximov, G.V., Filipović, M., Trifunović, B.V. \& Mišović, M.M. (1994). Mogućnost korišćenja ramanske spektroskopije u proucavanju 
otpornosti inbred linija kukuruza prema uslovima stresa. Savremena poljoprivreda, 42, No. 1-2, pp. 5-19.

7. Radenović, Č., Jeremić, M., Maximov, G.V., Mišović, M.M. \& Trifunović, B.V. (1994). Resonance Raman spectra of carotenoids in the maize seed tissue - a new approach in studies on effects of temperatures and other environmental factors on the state of vital functions. J. of Sci. Agricul. Res., 55, No. 4, pp. 33-47.

8. Radenović, Č., Jeremić, M., Maximov, G.V., Mišović, M.N., Selaković, D. \& Trifunović, B.V. (1995). Rezonantni ramanski spektri semena kukuruza i njihova primena u proucavanju životnih funkcija. In: Oplemenjivanje, proizvodnja i iskorišćavanje kukuruza - 50 godina Instituta za kukuruz Zemun Polje (pp. 291-296). Beograd: Institut za kukuruz Zemun Polje.

9. Radenović, Č., Jeremić, M., Maximov, G.V., Mišović, M.N. \& Selaković, D. (1998). Resonance Raman spectra of carotenoides in the maize kernel - a contribution to the evaluation of the kernels resistance to the temperature and the chemical composition of soil. Proc. Nat. Sci., Matica Srpska, Novi Sad, 95, pp. 41-50.

10. Radenović, Č.N., Maksimov, G.V. \& Grodzinskij, D.M. (2015). Identification of Organic Molecules in Kernels of Maize Inbred Lines Displayed with Infrared Spectra. Fisiol. rast. genet., 47, No. 1, pp. 15-24.

11. Radenovich, Ch., Maksimov, G.V., Tutyaev, E.V., Shutova, V.V., Delich, N., Chamdzhia, Z., Pavlov, J. \& Jovanovic, J. (2016). Identification of organic compounds in corn hybrids (Zea mays L.) of Serbian breeding using infrared spectra. Sel'skokhozyaystvennaya biologiya, 51, No. 5, pp. 645-653 [in Russian].

12. Radenovich, Ch., Maksimov, G.V., Tyutyaev, E.V., Shutova, V.V., Delich, N., Chamdziya, Z., Pavlov, Yo. \& Jovanovich, Zh. (2016). Identification of characteristic organic molecules in kernels of maize (Zea mays L.) hybrid grain using infrared spectroscopy. Agricult. Biol., 51, No. 5, pp. 645-653.

13. Macura, S. \& Radenović, Č. (2016). In order to acquire better knowledge on a biological system, besides the genome and proteome it is necessary to know its metabolome, i.e. concentrations of all metabolites and their interactions. Written correspondence, Mayo Clinic, Rochester and Maize Research Institute, Zemun Polje, Belgrade and vice versa.

14. Kols, O.R., Maksimov, G.V. \& Radenovich, Ch.N. (1993). Biophysics of rhythmic excitation. MGU, Moskva [in Russian].

15. Radenović, Č. (1998). Savremena biofizika. 5. Transportni procesi kroz membranu (pp. 1-90). Beograd: Velarta.

16. Radenović, Č., Marković, D. \& Veljović-Jovanović, S. (2001). Savremena biofizika. 7. Biomembrane: struktura, dinamika i funkcija (pp. 1-100). Beograd: Velarta.

17. Vollhardt, P.C. \& Schore, N.E. (1996). Organic Chemistry. N.Y.: W.H. Freeman and Company.

18. White, P.J. \& Johnson, L.A. (2003). Corn: Chemistry and Technology. Minnesota: American Association of Cereal Chemists.

19. Amir, R.M., Anjum, F.M., Khan, M.I., Khan, M.R., Pasha, I. \& Nadeem, M. (2013). Application of Fourier transform infrared (FTIR) spectroscopy for the identification of wheat. J. Food Sci. Technol., 50, pp. 1018-1023.

20. Jackson, M. \& Mantsch, H.H. (2006). Infrared spectroscopy, ex vivo tissue analysis. In: Biomedical Spectroscopy (pp. 131-156). Encyclopedia of Analytical Chemistry, John Wiley \& Sons Ltd.

21. Chalmers, J.M. (2002). Mid-infrared Spectroscopy: Anomalies, Artifacts and Common Errors in Using Vibrational Spectroscopy Techniques. In: Handbook of Vibrational Spectroscopy, John Wiley \& Sons Ltd.

22. Yu, P., McKinnon, J.J., Christensen, C.R. \& Christensen, D.A. (2004). Imaging Molecular Chemistry of Pioneer. Corn J. Agric. Food Chem., 52, pp. 7345-7352.

23. Skoog, D.A., Holler, F.J. \& Crouch, S.R. (2007). Principles of Instrumental Analysis. Belmont: Thomson Higher Education, USA.

Received 23.02.2018 


\title{
ИССЛЕДОВАНИЕ МЕТОДАМИ ИНФРАКРАСНОЙ СПЕКТРОСКОПИИ ВАЛЕНТНЫХ И ДЕФОРМАЦИОННЫХ КОЛЕБАНИЙ ХИМИЧЕСКИХ СВЯЗЕЙ В ФУНКЦИОНАЛЬНЫХ ГРУППАХ ОРГАНИЧЕСКИХ СОЕДИНЕНИЙ, СОДЕРЖАЩИХСЯ В ЗЕРНАХ ИНБРЕДНЫХ ЛИНИЙ КУКУРУЗЫ
}

\author{
Ч.Н. Раденович ${ }^{1,2 *}$, Г.В. Максимов ${ }^{3}$, В.В. Шутова ${ }^{4}$, Н.С. Делич ${ }^{1}$, М.В. Миленкович1, \\ М.Д. Павлович \\ ${ }^{1}$ Институт кукурузы «Земун Поле», Белград, Сербия \\ ${ }^{2}$ Факультет физической химии Белградского университета, Белград, Сербия \\ ${ }^{3}$ Биологический факультет Московского государственного университета \\ им. М.В. Ломоносова, Москва, Россия \\ ${ }^{4}$ Биологический факультет Национального исследовательского Мордовского \\ государственного университета им. Н.П. Огарёва, Республика Мордовия, Саранск, \\ Россия \\ ${ }^{5}$ Институт общей и физической химии, Лаборатория биохимии и биофизики, \\ Белград, Сербия \\ *Контакт-автор: radenovic@sbb.rs
}

В работе рассмотрено применение метода инфракрасной спектроскопии зерен элитных инбредных линий кукурузы ZPPL 186, ZPPL 225 и M1-3-3 Sdms с целью определения структурных характеристик органических соединений и их неустойчивого состояния. Выдвинута гипотеза о необходимости изучения различных многочисленных спектральных полос, неисследованных до сих пор, появляющихся в различных формах (полосы низкой интенсивности, одиночные или сгруппированные), объяснения природы и динамики их образования. Такие спектральные полосы наблюдались в диапазоне волн 400-2925 см с $^{-1}$ они вызваны различными типами колебаний (валентных и деформационных) органических соединений: алкенов, ароматических соединений, спиртов, простых эфиров, карбоновых кислот, сложных эфиров, аминов, амидов, алканов, нитросоединений, кетонов, альдегидов, алкинов, нитрилов и фенолов. Таким образом, можно установить не только структуру органических соединений зерен наблюдаемых инбредных линий кукурузы, но также указать их неустойчивые, конформационные и функциональные свойства. В работе впервые акцентирована важность изучения формы, кинетики и интенсивности спектральных полос, выражающих неустойчивые процессы в биологических системах и биоактивных органических молекулах.

Ключевые слова: Zea mays L., инбредные линии кукурузы, зерно, инфракрасные спектры, спектральные полосы.

\section{ДОСЛІДЖЕННЯ МЕТОДАМИ ІНФРАЧЕРВОНОЇ СПЕКТРОСКОПІЇ ВАЛЕНТНИХ І ДЕФОРМАЦІЙНИХ КОЛИВАНЬ ХІМІЧНИХ ЗВ'ЯЗКЇВ У ФУНКЦІОНАЛЬНИХ ГРУПАХ ОРГАНІЧНИХ СПОЛУК, ЩО МІСТЯТЬСЯ В ЗЕРНАХ ЇНБРЕДНИХ ЛІНІЙ КУКУРУДЗИ}

Ч.Н. Раденович ${ }^{1,2 *}$ Г.В. Максимов ${ }^{3}$, В.В. Шутова ${ }^{4}$, Н.С. Деліч1, М.В. Міленкович1, М.Д. Павлович ${ }^{5}$, М.В. Белянськи

${ }^{1}$ Їнститут кукурудзи «Земун Поле», Белград, Сербія

${ }^{2}$ Факультет фізичної хімії Бєлградського університету, Бєлград, Сербія

${ }^{3}$ Біологічний факультет Московського державного університету

ім. М.В. Ломоносова, Москва, Росія

${ }^{4}$ Біологічний факультет Національного дослідного Мордовського державного

університету ім. Н.П. Огарьова, Республіка Мордовія, Саранськ, Росія

5 Їнститут загальної та фізичної хімії, Лабораторія біохімії та біофізики, Бєлград,

Сербія

*Контакт-автор: radenovic@sbb.rs

У роботі розглянуто застосування методу інфрачервоної спектроскопії зерен елітних інбредних ліній кукурудзи ZPPL 186, ZPPL 225 і M1-3-3 Sdms з метою визначення 
структурних характеристик органічних сполук та їх нестійкого стану. Висунуто гіпотезу про необхідність вивчення різних численних спектральних смуг, недосліджених досі, що з'являються в різних формах (смуги низької інтенсивності, поодинокі або згруповані), пояснення природи і динаміки їх утворення. Такі спектральні смуги спостерігали в діапазоні хвиль 400-2925 см с $^{-1}$ вони спричинені різними типами коливань (валентних і деформаційних) органічних сполук: алкенів, ароматичних сполук, спиртів, простих ефірів, карбонових кислот, складних ефірів, амінів, амідів, алканів, нітросполук, кетонів, альдегідів, алкінів, нітрилів і фенолів. Отже, можна встановити не тільки структуру органічних сполук зерен досліджуваних інбредних ліній кукурудзи, а й вказати їх нестійкі, конформаційні та функціональні властивості. У роботі вперше акцентована важливість вивчення форми, кінетики та інтенсивності спектральних смуг, що виражають нестійкі процеси в біологічних системах і біоактивних органічних молекулах.

Ключові слова: Zea mays L., інбредні лінії кукурудзи, зерно, інфрачервоні спектри, спектральні смуги. 